\title{
Determinants of the Capital Structure of Companies Listed on the Stock Exchanges of Argentina, Brazil and Chile: An Empirical Analysis of the Period from 2007 to 2016
}

\author{
Marcelo Rabelo Henrique ${ }^{1}$, Sandro Braz Silva ${ }^{1,2}$, Antônio Saporito ${ }^{1,2} \&$ Sérgio Roberto da Silva ${ }^{2}$ \\ ${ }^{1}$ Department of Accounting Sciences, Federal University of São Paulo, São Paulo, Brazil \\ 2 Administration Department, University Center of the Inaciana Educational Foundation "Padre Sabóia de \\ Medeiros" (FEI), São Paulo, Brazil \\ Correspondence: Marcelo Rabelo Henrique, Department of Accounting Sciences, Federal University of São \\ Paulo, Osasco, SP., Street Angélica, 100 - Jd. Das Flores, Brazil. Tel: 55-11-995-371-281. E-mail: \\ marcelo@mrhenriqueconsult.com.br
}

Received: February 25, 2020

Accepted: April 17, 2020

Online Published: May 10, 2020

doi:10.5539/ijef.v12n6p18

URL: https://doi.org/10.5539/ijef.v12n6p18

\begin{abstract}
The present investigation refers to the determinants of the capital structure, using the technique of multiple regression through Panel Data of open capital companies in the stock exchanges of Argentina, Brazil and Chile, in order to know the behavior of determinants of the capital structure in relation to Trade-Off Theory (TOT) and Pecking Order Theory (POT). The POT offers the existence of a hierarchy in the use of sources of resources, while the TOT considers the existence of a target capital structure that would be pursued by the company. Sixteen accounting variables were used, in which five are dependent (related to indebtedness) and eleven are independent variables (explaining the determinants of the capital structure). It is observed that, with the use of the Panel Data, the determinants that seem to influence in a more accentuated way the levels of debt of the companies are: current liquidity, tangibility, return to shareholders, return of assets, sales growth, asset growth, market-to-book and business risk measured by the volatility of benefits. Suggestions for future research include the use of Panel Data to analyze other factors that may influence indebtedness, mainly taxes and dividends, as well as a deeper analysis of factors that may influence the speed of adjustment towards the supposed objective level.
\end{abstract}

Keywords: Trade-Off Theory, Pecking Order Theory, debt, determinants of the capital structure, analysis of multiple linear regression

\section{Introduction}

The innumerable research done to try to exhaust the issue of capital structure is endless, and, due to some variables, this issue will always be in evidence. That is, the ways of data collection and independent variables will be chosen according to an econometric model, the econometric tools used, the types of companies, the legal characteristics of the accounting-financial field, among others.

In addition, in competitive and fine markets, it is possible to identify different forms of leverage and corporate strategies. So, "how do companies choose their capital structure?" (Myers, 1984). Very little is known about the capital structure, and it is not known how companies choose debts and equity.

\subsection{Justification}

The way managers combine sources of financing is an important decision for the company's financial and strategic context. The capital structure refers to the way in which companies use the sources of origin, whether their own or those of third parties, to apply in equity assets and in activities that demand them.

The choice of the best combination of the sources of capital structure resources is still a recurring theme in finance. Studies on the effects of financial leverage on decisions to better allocate resources in organizations historically contributed to the advancement of theoretical discussions (Camilo, Xavier, De Mello, \& Marcon, 2010, p. 110).

Among the issues addressed by the theory of corporate finance, the part related to the capital structure is one of 
the most complex and controversial. Despite having a series of theoretical and empirical research, this issue does not have a prompt and unanimous response on what is the best or most appropriate capital structure for an organization (Myers, 1984; Bradley, Jarrell, \& Kim, 1984; Titman \& Wessels, 1988), and for one person.

In addition, inquiries related to the choice of financing - indebtedness versus equity - have gained importance for management strategy research. In a short space of time, there was a significant increase in the attention devoted to the management strategy literature on financial aspects (Sandberg, Lewellen, \& Stakey, 1987; Kochhar, 1997).

From the article by Modigliani and Miller (1958), researchers analyze the factors that affect the capital structure of companies (Chen \& Zhao, 2006; Myers, 1977; Titman \& Wessels, 1988). In a world without disagreements, the capital structure is irrelevant to the conception of the company's value and, therefore, there should be no preference for a certain type of capital structure (Modigliani \& Miller, 1958). However, in the real world, each company can opt for a different degree of leverage (Choi, Saito, \& Silva, 2015).

Therefore, the rationale for this study is to evaluate the capital structure of the companies listed on the stock exchanges of Argentina, Brazil and Chile, in the period from 2007 to 2016.

\subsection{Research Problem, Objectives and Hypothesis}

The observation of the identified elements, constant in the theories that debate about capital structure and the investigated authors, allows to formulate the following research problem: How is the behavior of the determinants of the capital structure of companies listed on the stock exchanges of values from Argentina, Brazil and Chile, on the prism of financial theories of pecking order and trade-off, in the period from 2007 to 2016 ?

The general objective of this research is to compare the behavior of determinant variables of the capital structure of companies listed in the stock exchanges of Argentina, Brazil and Chile, considering the specific factors of the companies. In this way, the institutional aspects (number of employees and open units) and economic aspects (market niche, actions in internal and external markets) will not be evaluated; the analysis will be limited, just, to the specific factors of the company.

To better outline the study, some specific objectives were scored, as follows:

a) Test the relationship of the independent variables with some types of indebtedness in Argentine, Brazilian and Chilean stock market companies;

b) Select the independent variables to be approved in the study;

c) Analyze the behavior of variables of the determinants of the capital structure of companies listed on the stock exchanges of Argentina, Brazil and Chile, under the theories of capital structure: Trade-off and Pecking Order.

The formulation of the hypotheses of this research was based on the theoretical reference, through the reading of empirical studies already carried out. To start, Booth et al. (2001) and Bastos and Nakamura (2009) empirically distinguished that the hypotheses between theoretical currents have proved a difficult task. In many situations, the behavior of one variable can be explained by one theory, pray by another. In addition, theoretical currents are conflicting in seeking explanations for the behavior of some variables.

A fundamental issue faced when conducting business evaluations is: At what level of detail will the evaluation be? On the one hand, adding more details would allow analysts the opportunity to use more information to make better forecasts on each item. On the other hand, it would be necessary to generate more inputs, raising the potential for errors to occur on each one (Damodaran, 2007).

For Myers and Majluf (1984), Myers (1984) and Nakamura et al. (2007), the pecking order theory proposes the use of indebtedness to finance assets and actions in new opportunities for organizational growth, in which managers end up in the hierarchy of resources to place bets on growth opportunities. In this condition, it is possible to expect the most profitable companies to be less indebted. Ross (1977) and, Harris and Raviv (1991) argues that the relationship between profitability and level of indebtedness is positive. On the other hand, in the literature, there is the counterpoint of Brito, Corrar, and Batistella (2007), who mention that profitability is not decisive for the capital structure of organizations.

Through this discussion, it was possible to construct two hypotheses, one related to the return of shareholders and the other to the return of company assets. They are:

Hypothesis 1: The relationship between return to shareholders and indebtedness indicators is negative.

Hypothesis 2: The relationship between asset return and debt indicators is negative.

However, in the vision of Myers and Majluf (1984), companies use their assets as a guarantee of indebtedness 
when they judge that there is a need for investments in various opportunities. Thus, they hinder risky strategies used by shareholders who tend to get wealth from their creditors. Brito, Corrar and Batistella (2007) affirm that there is a negative relationship between the composition of assets and total indebtedness. Therefore, the following hypothesis is proposed:

Hypothesis 3: The relationship between asset growth and indebtedness indicators is positive.

Another aspect that led to the construction of another hypothesis was the fact that, in previous studies, companies with growth potential tend to have greater flexibility to invest, increasing the indebtedness of organizations, which points to a negative relationship between growth and indebtedness (Kayo \& Famá, 1997; Gaud, Jani, Hoesli, \& Bender, 2005). In another conception, Brito, Corrar, and Batistella (2007) found a positive connection of growth in relation to total long-term indebtedness, there being no relation to short-term indebtedness. Gomes and Leal (2001) point to a positive relationship between the level of growth and the indebtedness of companies, as the companies that grow more demand more resources to better manage these opportunities, and seek these resources outside the company. Therefore, it is split for the following hypothesis:

Hypothesis 4: The relationship between sales growth and indebtedness indicators is negative.

For Titman and Wessels (1988), tangible assets help companies to expand their indebtedness indicators, in which they offer as payment guarantees. The logic for this type of thinking is that the guarantee, in return for the debt, minimizes the theory of agency and problems of conflicts between creditors and shareholders, owners, managers of business organizations. Thus, according to Myers and Majluf (1984), that minimizes risky strategies of the owners with the interest of appropriating creditors' wealth. Therefore, another hypothesis arises:

Hypothesis 5: The relationship between tangibility of assets and debt indicators is positive.

Bastos, Nakamura, and Basso (2009) and Correa, Basso, and Nakamura (2013) found strong influence of the variable that deals with the current liquidity index, the result of which was a negative relationship between liquidity and indebtedness, confirming the theory hypothesis of pecking order. Thus, the hypothesis for this variable is:

Hypothesis 6: The relationship between current liquidity and debt indicators is negative.

The trade-off theory presents a positive relationship between the level of payment of taxes and the level of indebtedness. Correa, Basso, and Nakamura (2013) and Bastos, Nakamura, and Basso (2009) found different evidence to this assumption of the theory, in which the relationship between the payment of income tax is negative to total indebtedness, to the value of market and short and long term financial. With this, it is expected that the hypothesis to be presented is:

Hypothesis 7: The relationship between the level of income tax payment and indebtedness indicators is negative.

\section{Literature Review}

\subsection{Evolution of Capital Structure Theories}

From these studies on capital structure, a long discussion was established, that is, many works were carried out and other theories were elaborated in the attempt to explain what determines the use of own or third-party capital by companies, in addition to the ideal mix between funding sources.

In addition to the works that are concerned with discussing the differences and testing the theories developed by M\&M and the traditionalists, there is a class of authors who prioritized the discussion of bankruptcy costs and their influence on the definition of the structure of business capital.

\subsection{Trade-Off Theory (TOT)}

The trade-off theory (TOT) is based on fiscal economies related to the use of debts and expected bankruptcy costs, derived from excess indebtedness. It was from the combination of these two factors that what came to be called "trade-off theory" was established (Nakamura, Martin, \& Kayo, 2004; Nakamura et al., 2007).

According to this theory, companies have an objective level of debt to adjust gradually over time. Thus, the more lucrative the company, the more taxable benefits she has to protect, then, the greater the use of debt as a source of financing. This occurs due to the tax benefit obtained through this form of collection.

\subsection{Pecking Order Theory (POT)}

Pecking order theory (POT) was recommended by Donaldson (1961), who perceived, in the management of large companies, the predilection of internally generated resources to finance their activities with external 
resources. On these ideas of Donaldson (1961), Myers (1984) and Myers and Majluf (1984) formally point to the hierarchy of preferences, indicated in table 1.

Table 1. Order of preference in the use of resources

\begin{tabular}{cl}
\hline PREFERENCE & \multicolumn{1}{c}{ DESCRIPTION } \\
\hline First & Use internally generated financial resources (retained benefits). \\
Second & Capture third party resources (loans, financing, issuance of debentures) and adjust dividend policies. \\
Third & Issuance of new shares. \\
\hline
\end{tabular}

Source: Adapted by Myers (1984) and Myers and Majluf (1984).

\subsection{Optimal Capital Structure}

Research on the capital structure of companies is considered the most important in the area of Finance. Various theoretical approaches have been discussed and tested in the financial literature.

According to Perobelli and Famá (2003), in relation to the methodological elegance of the works related to the subject, the verification of the existence of an optimal structure, to be pursued by companies, was never achieved. Parallel to this discussion, new theories emerged that sought to explain the choice of capital structure by companies based on certain attributes. The discussion, therefore, migrated from a single structure to the most appropriate structure to each company profile. Some relevant works in this line were those developed by Remmers et al. (1974); Toy et al. (1974); Scott and Martin (1975); Stonehill et al. (1975); Ferri and Jones (1979); DeAngelo and Masulis (1980); Bradley, Jarrel and Kim (1984); Myers and Majluf (1984); Myers (1984); Lumby (1991); Thies and Klock (1992); Balakrishnan and Fox (1993); Allen (1995) and Rajan and Zingales (1995). (Perobelli \& Famá, 2003), Zavala and Salgado (2019), Ramos Júnior, Santos, Gaio, Stefanelli, and Passos (2019), Mendonça, Martins, and Terra (2019), Mamede, Jardim, Nakamura, Jones, and Nakamura (2019), Demirgüç-Kunt, Peria and Tressel (2020).

\section{Method}

The present empirical research completed, as methodological features, the following steps: period of analysis and accounting-financial data; method, methodological approach, nature and research strategies; and analysis, diversification and variable tools.

\subsection{Period of Analysis and Accounting-Financial Data}

This research proposal covers the period from 2007 to 2016, whose data were extracted from the Economic system, especially from the balance sheets and the statements as results of the years, related to the open capital companies listed in the scholarships of Argentina, Brazil and Chile, the annual financial statements closed in December of each year being considered, with a duration of ten years for the analysis.

The classification of companies in sectors was also extracted from the Economática data bank, and the sample was composed of those Argentine, Brazilian and Chilean non-financial companies. The choice of annual accounting-financial reports was given in relation to the seasonality of some companies.

\subsubsection{Variables}

All variables, dependent and independent, used in the performance of econometric tests were defined based on the theoretical reference. Data on the specific factors of the companies were collected directly from the Economica software, in the fourth quarter of 2018, which provides both accounting and market data. Therefore, it is primary data. These data include the economic-financial variables of open companies. The quarterly data come from equity balances, income statements for the year and market information available in the database itself.

The variables that make up this study are presented in Tables 2 and 3, which state their names, acronyms and calculation formulas: 
Table 2. Dependent variables

\begin{tabular}{lcc}
\hline \multicolumn{1}{c}{ Research Variable } & Initials & Formula \\
\hline Total indebtedness & ET & $\frac{\text { Current liabilities + Non-current liabilities }}{\text { Total active }}$ \\
Short term indebtedness & ECP & $\frac{\text { Current liabilities }}{\text { Total active }}$ \\
Long-term indebtedness & ELP & $\frac{\text { Non-current liabilities }}{\text { Total active }}$ \\
Short-term burdensome financial indebtedness & EOCP & Debentures and short-term financing \\
Onerous debt finance long term & EOLP & Debets at book value \\
\end{tabular}

Source: Prepared by the author.

The dependent variables presented in Table 2 represent the indebtedness indicators and were used in the panel data regression models in the execution of this study. They were based on readings from previous research.

Table 3. Independent variables

\begin{tabular}{|c|c|c|}
\hline Research Variable & Initials & Formula \\
\hline Current liquidity & LC & $\frac{\text { Current assets }}{\text { Current liabilities }}$ \\
\hline Tangibility & TANG & $\frac{\text { Active fixed assets }+ \text { Inventories }}{\text { Total active }}$ \\
\hline Return to investors & ROE & $\frac{\text { Net profit }}{\text { Net worth }}$ \\
\hline Return on investment & ROA & $\underset{\text { Total active }}{\underline{\text { EBIT }}}$ \\
\hline Sales growth & CVD & $\frac{\text { Net income }}{\text { Net }_{t}(-) \text { Net income }_{t-1}} \underline{t-1}_{t}$ \\
\hline Asset growth & CAT & $\frac{\underline{\text { Total active }}_{t}}{\text { Total }_{\text {active }} t-1}$ \\
\hline Level of payment of income tax & IR & $\frac{\text { Value of income tax }}{\text { EBIT }}$ \\
\hline Fiscal Economy & $\mathrm{EF}$ & $\frac{(\text { Depreciation }+ \text { Amortization })}{\text { EBITDA }}$ \\
\hline Profitability & PROF & $\frac{\underline{\text { EBITDA }}}{\text { Total active }}$ \\
\hline Growth expected by the market value differential & МTB & $\frac{\text { Market value of assets }}{\text { Book value of assets }}$ \\
\hline Business risk measured by profit volatility & RSK & $\frac{(\text { Standard deviation EBIT }- \text { Media })}{\text { Net operating income }}$ \\
\hline
\end{tabular}

Source: Prepared by the author.

The market value of the asset was calculated in accordance with Rajan and Zingales (1995), where the market value of the asset is (almost) equal to the asset minus the net asset book value. The market value of the net worth was obtained from the Economic system, being equal to the price of the closing of the action times the total shares of the company.

The data of these independent variables were extracted from the balance sheets and income statements of the periods under study, from January 2007 to December 2016, with annual periodicity of the Economica software.

\subsubsection{Analysis Tools}

Four tools were used for the analysis of this study. The first is the descriptive analysis of the data by means of the average and the standard deviation of each dependent and independent variable of each country (Brazil, Argentina and Chile). The second is Pearson's correlation, whose idea is to evaluate the existence or not of correlation between two variables. If there is a high correlation between two variables (from 0.7 or $70 \%$ ), it 
means that these variables are influencing the final result of the model. Correlation values may vary between -1 and +1 (correlation between $-100 \%$ and $+100 \%$ ).

For example, when analyzing the correlation between total indebtedness and current liquidity of the three countries (Brazil, Argentina and Chile, or according to the panels in Table 2, A, B and C, respectively), it is possible to observe a negative correlation between the two on-screen variables in the three countries: $53 \%$ in Brazil, $49.3 \%$ in Argentina and $15.6 \%$ in Chile, all at the $1 \%$ level of significance. This means that there is no high correlation between the two variables in the three countries, not influencing the final result of the model for this type of indebtedness.

The third data analysis tool is the Variance Inflation Factor (VIF). The use of the VIF is to know if there are multicollinearity problems. This tool varies between 0 and 1, promoting the idea that, if it is greater than 1 , there is multicollinearity. Finally, the fourth tool is the regression of panel data and test derivatives (from $\mathrm{F}$ de Chow, Hausman and LM from Breusch-Pagan).

According to Wooldridge (2006), the use of the panel data regression technique allows to accompany an individual or groups of individuals over time, that is, in the case of a company, it is possible to accompany the variation of certain variables in different periods of time, thus carrying out the analysis that combines time series and cutting data with some relevance (Terra, 2002).

Bowman (1980) perceived a very large difference in bad specification when he worked with a cross-correlation between accounting and market data, believing that with the accounting data that bad specification is much smaller. Therefore, Nakamura et al. (2007) and Terra (2002) reinforce another methodological contribution in the use of this technique: avoid problems of specification of the econometric model, which eliminates the effects of the omitted variables, even if they have not been observed.

Three types of tests were performed using panel data regression: (1) the Chow F test assesses the adequacy of the panel test for the variables presented; (2) Hausman's evaluates the fixed and random variables of the test; and (3) that of LM of Breusch-Pagan serves to validate the test.

At the base of the panel are the values of R2, which is the square of Pearson's correlation and adjusted R2, called R2a, which presents the correlation adjustment for the number of samples used in the analysis (Johnson \& Wichern, 1998 ). It is observed that the values decrease slightly according to the adjustments, confirming the need for this calculation. Therefore, it is possible to observe that the explanatory power of the total indebtedness variable for Brazil was 79.5\%; for Argentina, 72.7\%; and for Chile, 17.5\%. This means that the more elaborate model has more explanation with the data of Brazilian companies, followed by Argentine companies and, with some distance, from Chilean companies.

From this stage, the panel data regression offers a wide possibility of analysis of various factors in the econometric analysis and converges with the advantages presented above.

\subsubsection{Econometric Models}

The application of the econometric models was made from this general equation:

$$
\begin{aligned}
& E_{i t}=\beta_{0}+\beta_{1 i} L C_{-i t}+\beta_{2 i t} T A N G_{i t}+\beta_{3 i t} R O E_{i t}+\beta_{4 i t} R O A_{i t}+\beta_{5 i t} C V D_{i t}+\beta_{6 i t} C A T_{i t}+\beta_{7 i t} I R_{i t}+\beta_{8 i t} E F_{i t}+\beta_{9 i t} M T B_{i t}+ \\
& \beta_{10 i t} R S K_{i t}+\mu_{i t} \\
& \text { Equation (1) }
\end{aligned}
$$

Each study variable is represented by the respective acronyms:

Ei: represents the dependent variables that deal with the indebtedness of companies;

LC_it: represents the independent variable of current liquidity;

TANGIT: represents the independent tangibility variable;

ROEit: represents the independent variable of return to shareholders;

ROAit: represents the independent variable of return on investment;

CVDit: represents the independent variable of sales growth;

CATIT: represents the independent variable of asset growth;

IRit: represents the independent variable of income tax payment level;

EFIT: represents the independent fiscal economy variable;

MTBit: represents the independent market-to-book variable;

RSKit: represents the independent business risk variable; 
it: represents that the variables are used for all proposed linear multiple regression models of panel data: POLS, Fixed effects and Random effects;

t: represents the time.

\section{Results}

This chapter will present and analyze the results obtained in this investigation.

The first step, described in section 4.1, sought to examine the relationship between historical market values and the capital structure of Argentine, Brazilian and Chilean companies, in order to identify the behavior of the average level of indebtedness and standard deviation of the variables studied between 2007 and 2016.

The second step, described in section 4.2, sought to test the intensity and the sense of the relationships between the variables by means of Pearson's correlation coefficient, together with the Variance Inflation Factor, to identify possible multicollinearity problems.

Finally, section 4.3 presents the summary of the main results found in this study.

\subsection{Descriptive Statistics of the Variables}

Table 4 presents the average level of indebtedness and the standard deviation of the variables studied, between 2007 and 2016, in the three countries analyzed.

Table 4. Descriptive statistics of variables

\begin{tabular}{|c|c|c|c|c|c|c|}
\hline \multirow[b]{2}{*}{ Variables } & \multicolumn{2}{|r|}{ Brasil } & \multicolumn{2}{|c|}{ Argentina } & \multicolumn{2}{|c|}{ Chile } \\
\hline & Average & $\begin{array}{l}\text { Average Standard } \\
\text { Deviation }\end{array}$ & Average & $\begin{array}{l}\text { Average Standard } \\
\text { Deviation }\end{array}$ & Average & $\begin{array}{c}\text { Average Standard } \\
\text { Deviation }\end{array}$ \\
\hline \multicolumn{7}{|c|}{ Panel A - Dependent Variables } \\
\hline ET & 0,540 & 0,187 & 0,536 & 0,187 & 0,385 & 0,175 \\
\hline ECP & 0,232 & 0,120 & 0,339 & 0,169 & 0,161 & 0,094 \\
\hline ELP & 0,308 & 0,160 & 0,197 & 0,157 & 0,224 & 0,141 \\
\hline EOCP & 0,079 & 0,067 & 0,045 & 0,050 & 0,023 & 0,031 \\
\hline EOLP & 0,194 & 0,140 & 0,018 & 0,026 & 0,109 & 0,136 \\
\hline \multicolumn{7}{|c|}{ Panel B - Independent Variables } \\
\hline $\mathrm{LC}$ & 2,003 & 1,578 & 1,339 & 0,711 & 4,204 & 31,613 \\
\hline TANG & 0,352 & 0,246 & 0,543 & 0,237 & 0,488 & 0,257 \\
\hline ROE & 0,054 & 0,617 & 0,038 & 0,449 & 0,082 & 0,206 \\
\hline ROA & 0,078 & 0,109 & 0,092 & 0,091 & 0,074 & 0,127 \\
\hline CVD & 0,230 & 1,794 & 0,720 & 8,132 & 49,572 & 1440,375 \\
\hline CAT & 0,158 & 0,807 & 0,479 & 5,444 & 11,979 & 393,817 \\
\hline IR & 0,026 & 0,277 & 0,411 & 1,710 & 0,132 & 1,414 \\
\hline ECND & 1,080 & 17,679 & 1,186 & 8,665 & 0,513 & 3,531 \\
\hline MTB & 268,908 & $3.467,92$ & 0,490 & 0,707 & 0,726 & 1,276 \\
\hline PLD & $-0,753$ & 19,023 & 0,008 & 0,548 & $-13,334$ & 95,079 \\
\hline
\end{tabular}

Source: Research data.

Ps.: (*) higher averages; (**) lower averages.

The data in panel A reveal, on average, in the period from 2007 to 2016, between Argentina, Brazil and Chile, the following results, in relation to the characteristics of indebtedness (dependent variables) in those countries:

- Brazil has the highest average in total indebtedness, making up 54\% of its sources of resources; on the other hand, Chile has the lowest average, around 38.5\%;

- The country with the highest average short-term debt is Argentina, with 33.9\%; Chile has the lowest average short-term debt, around $16 \%$;

- For long-term, onerous short-term and long-term borrowings, Brazil has the highest averages, with 30.8\%, 7.9\% and $19.4 \%$, respectively; Argentina has the lowest average long-term and long-term borrowings, with $19.7 \%$ and $1.8 \%$, respectively; Chile marked presence with the lowest average only in short-term burdensome indebtedness, with $2.3 \%$.

Regarding the behavior of independent variables, in which they represent the determining variables of the capital structure, the results reported in panel B of table 4 were: 
- Most of the lower averages were for Brazilian companies (in Tangibility, ROA, Sales and Asset Growth, Income Tax Payment Level), while in Argentina, companies have the highest averages of determining variables of the capital structure (Tangibility, ROA, Income Tax Payment Level, Fiscal Economy and Business Risk); Chilean companies have four variables that determine the capital structure with the highest averages (Current Liquidity, ROE, Sales and Asset Growth);

- Current Liquidity, which translates as the capacity that companies have in liquidating their short-term debts using short-term assets, had greater prominence in Chile, totaling, on average, 4.2, that is, for each unit Monetary short-term debt (obligations), companies, on average, have four units to withdraw these debts (economically, assets and rights activated);

- Companies in Argentina aim to have 54\% of tangible assets, that is, more than in Chile and, especially, in Brazil, whose Tangibility indicator is the lowest (35\%);

- Regarding the indicators of return to partners and entrepreneurship, Chilean companies had a higher average with the ROE of $8.2 \%$, and Argentine companies averaged 9.2\% with the ROA; Brazilian companies have an average very similar to Chilean companies, with the lowest averages, respectively, $7.8 \%$ and $7.4 \%$;

- If the Chilean companies had the highest averages with Sales Growth and Asset Growth, the Brazilian companies presented the lowest averages in these areas, with $23 \%$ and $15.8 \%$, respectively;

- Regarding taxes, Argentine companies have the highest averages with the variables Income Tax Payment Level and Fiscal Economy (respectively, $41 \%$ and 118\%); Brazilian companies presented an average of $2.6 \%$ for the first variable (the lowest average) and Chilean companies, $51 \%$ for the second variable (the lowest average);

- For the market-to-book variable, the companies with the highest averages were the Brazilian ones, followed by the Chilean and Argentine companies. Brazilian companies are perceived to have higher market values than Chilean and Argentine companies;

- The companies with the lowest business risks are Chilean companies, although with a very small average; Argentine companies have the highest averages in this regard.

It should be noted that Brazil went through a political and economic crisis in 2015 and 2016, with a negative GDP variation, being $3.77 \%$ and $3.59 \%$, respectively.

\subsection{Relationship between the Variables}

Before presenting and evaluating panel data, the advantages of this method should be clarified. The data, as seen in Table 4, is in a cross-section and, in the econometric literature, they are known as panel data, or also as longitudinal data. As an advantage, according to the simple calculation of Pearson's correlation, they allow the evaluation of the data between them, in addition to the influence of their relationships for the final result of the analysis, since it allows the evaluation of the explanatory variables on the dependent variable along of the period studied (Wooldridge, 2010).

Therefore, Table 5 presents the relationship between the 15 variables and their correlations for each country analyzed in the research (Brazil, Argentina and Chile). Wooldridge (2010) also comments on the advantage of using this method to observe possible omitted variables. So, this preliminary analysis, before the final evaluation, aims to present these possible variables and thus increase the accuracy of the analysis, as Cameron and Trividi (2005) did.

It is observed that the degree of freedom changes from one variable to another, as some variables have a 0.05 degree of freedom, or $95 \%$ assertiveness. This variation is a consequence of the analyzed data and this factor is indicated as advantageous by Brooks (2008), which indicates that the data are not fixed, that is, they can vary over time and according to other factors. Still, the author indicates the need to combine this data with the estimation time, thus varying the degree of freedom and minimizing the omitted variables of the analysis, cited above.

The panel data presented in Table 5 offers a relationship between several data on different lines, the first line is the constants. These constants are different for each country evaluated and for each factor of each country, for example, the gap begins with accounting indebtedness, where the ET constant is 0.637 for Brazil, 0.920 for Argentina and 0.322 for Chile; all with the same degree of freedom of 0.01. That is, for each ET factor the percentage of Brazil is $63.7 \%$, Argentina $92 \%$ and Chile only $32.2 \%$.

The Breusch-Pagan, F de Chow and Hausman tests were performed on the variables dependent on total indebtedness, short-term indebtedness and long-term indebtedness. Only the Hausman test in Chile had random effects, and in Brazil and Argentina had fixed effects. 
Next, the tests by Breusch-Pagan, F de Chow and Hausman were performed on the dependent variables of onerous financial indebtedness in the short and long term. All countries maintained the same effects in the respective variables.

The panel data show positive and negative correlations, some significant and others so small that they approach zero, indicating the lack of correlation. For this investigation, the highest negative values are indicated as more significant, since they indicate the inverse correlation between the results.

At the base of the panel are the values of $\mathrm{R}^{2}$, which is the square of Pearson's correlation and adjusted $\mathrm{R}^{2}$, called $\mathrm{R}^{2} \mathrm{a}$, which presents the correlation adjustment for the number of samples used in the Johnson and Wichern analysis (1998). It is noted that the value of ET for Brazil and Argentina shows a strong correlation, close to 75\%, while for Chile the correlation is weak (17.5\%).

Thus, panel data offers a wide possibility of analysis of various factors in the econometric analysis, which converges with the advantages presented above.

Table 5. Pearson correlation and variance inflation factor test

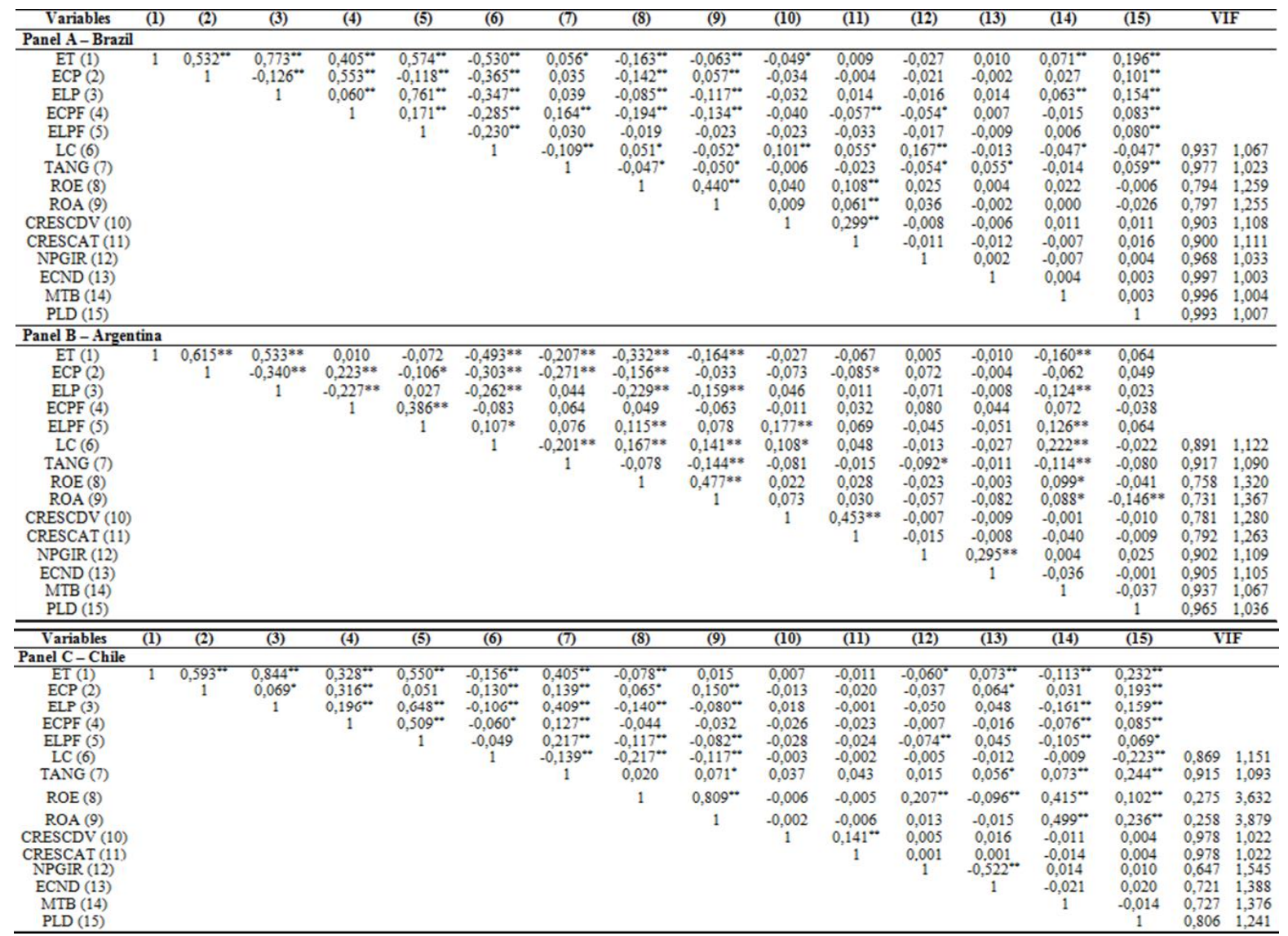

Source: Prepared by the author (research data).

Ps.: (*) The correlation is significant at the 0.05 level; (**) The correlation is significant at the 0.01 level.

Based on the findings in Table 5, Pearson's correlation between the variables presupposes the existence of a relationship between the determining factors of the capital structure and the levels of accounting and financial indebtedness. For Brazilian companies, only the Fiscal Economy (ECND) variable did not show significant correlation for the levels of accounting and financial indebtedness. On the other hand, for the Argentine companies, three indicators did not present a significant correlation with the levels of indebtedness, they are: the Level of Income Tax Payment (NPGIR), Fiscal Economy (ECND) and Business Risk Measured by the Volatility of Benefits (PLD). Finally, for Chilean companies, the variables Growth of Sales (CVD) and Growth of Assets (CAT) did not expose a significant correlation with any level of indebtedness.

The results of the Pearson correlation show that there is no high degree of correlation between the levels of 
accounting and financial indebtedness and the determining factors of the capital structure (correlation greater than $85 \%$ ), indicating that there are no high multicollinearity problems that may affect the results of the panel data regression model with the variables used. In addition, the VIF values shown in Table 5 also indicate the absence of multicollinearity, since the highest VIF value found was 3,879 , and only VIF values greater than 10 indicate multicollinearity problems among the variables (Gujarati \& Porter, 2011). In this way, the determinants of the capital structure selected in this study are able to explain the levels of indebtedness of the companies listed on stock exchanges in Brazil, Argentina and Chile.

For the realization of panel data regression, according to Fávero et al. (2009, p. 383), "some tests are used to define the best panel data model (POLS, fixed effects or random effects)". Thus, it was carried out: the Chow $F$ test, to verify if the intercept is the same (POLS) or different (fixed effects) for all the croos-sections; the Breusch-Pagan LM test, to find out if the variance of the residues that reflect the individual differences is equal (POLS) or different (random effects) from zero; and the Hausman test, to compare the results of the fixed effects model with that of random effects (Fávero et al., 2009). The tables with the results of these three tests are presented in the appendices of this research. Table 6 shows the results of the panel data regression.

Table 6. Panel data regression results

\begin{tabular}{|c|c|c|c|c|c|c|c|c|c|}
\hline \multicolumn{10}{|c|}{ Panel A - Accounting Indebtedness } \\
\hline \multirow{2}{*}{ Variables } & \multicolumn{3}{|c|}{ ET } & \multicolumn{3}{|c|}{ ECP } & \multicolumn{3}{|c|}{ ELP } \\
\hline & Brazil & Argentina & Chile & Brazil & Argentina & Chile & Brazil & Argentina & Chile \\
\hline Constant & $0,637^{*}$ & $0,920^{*}$ & $0,322^{*}$ & $0,288^{*}$ & $0,689^{*}$ & $0,125^{*}$ & 0,349 & \multirow{2}{*}{$\begin{array}{c}0,246^{*} \\
0,001\end{array}$} & $0,213^{*}$ \\
\hline LC & $-0,037^{*}$ & $-0,124^{\star}$ & $-6,39 \mathrm{E}-04^{*}$ & $-0,032 *$ & $-0,134^{\star}$ & $-3,55 \mathrm{E}-04^{*}$ & $-0,005^{\star}$ & & $-2,89 \mathrm{E}-04^{*}$ \\
\hline TANG & $-0,057^{*}$ & $-0,397 *$ & $0,155^{\star}$ & 0,003 & $-0,350^{*}$ & $0,078^{*}$ & $-0,060^{*}$ & $-0,041$ & $0,053^{*}$ \\
\hline ROE & $-0,022 *$ & $-0,073$ * & $-0,085^{\star}$ & $-0,026 *$ & $-0,056$ * & $-0,017$ & 0,004 & $-0,019$ & $-0,062^{*}$ \\
\hline ROA & $-0,03$ & $-0,172^{\star \star}$ & $-0,033$ & $0,102 *$ & 0,052 & 0,031 & $-0,132 *$ & $-0,212^{*}$ & $-0,091 *$ \\
\hline CVD & $-4,73 \mathrm{E}-04$ & $1,49 \mathrm{E}-03 * *$ & $-2,23 \mathrm{E}-06$ & $0,002^{*}$ & $-3,93 \mathrm{E}-04$ & $-2,23 \mathrm{E}-06^{* *}$ & $-0,003^{*}$ & $1,85 \mathrm{E}-03$ * & $-2,74 \mathrm{E}-08$ \\
\hline CAT & $0,007^{\star}$ & $-1,32 \mathrm{E}-03$ & $-8,1 \mathrm{E}-06$ & 0,005 * & $-3,72 \mathrm{E}-04$ & $-9,37 \mathrm{E}-08$ & 0,002 & $-8,93 \mathrm{E}-04$ & $-7,49 \mathrm{E}-06$ \\
\hline IR & 0,01 & $6,40 \mathrm{E}-04$ & $-0,002$ & 0,005 & $1,36 \mathrm{E}-03$ & $-0,001$ & 0,005 & $-1,21 \mathrm{E}-03$ & $-0,001$ \\
\hline ECND & $-9,49 \mathrm{E}-05$ & $-1,32 \mathrm{E}-04$ & $-1,09 \mathrm{E}-03$ & $-1,13 \mathrm{E}-04$ & $-2,28 \mathrm{E}-04$ & $3,14 \mathrm{E}-04$ & $1,78 \mathrm{E}-05$ & $6,16 \mathrm{E}-05$ & $-1,50 \mathrm{E}-03$ \\
\hline MTB & $2,32 \mathrm{E}-06$ * & $0,032^{*}$ & $-0,0002$ & $6,71 \mathrm{E}-07$ & $0,034^{*}$ & $8,42 \mathrm{E}-04$ & $1,65 \mathrm{E}-06^{* *}$ & $-0,004$ & $1,69 \mathrm{E}-03$ \\
\hline PLD & $1,74 \mathrm{E}-05$ & 0,014 & $2,46 \mathrm{E}-04^{*}$ & $1,22 \mathrm{E}-04$ & 0,001 & $1,55 \mathrm{E}-04^{*}$ & $-1,04 \mathrm{E}-04$ & 0,011 & $1,02 \mathrm{E}-04$ * \\
\hline$R^{2}$ & 0,818 & 0,763 & 0,181 & 0,815 & 0,802 & 0,729 & 0,790 & 0,067 & 0,850 \\
\hline$R^{2}$ Tight & 0,795 & 0,727 & 0,175 & 0,791 & 0,772 & 0,692 & 0,763 & 0,049 & 0,829 \\
\hline Panel B - Financial in & & & & & & & & & \\
\hline Variables & & & ECPF & & & & ELPF & & \\
\hline Variabies & Brazil & & Argentina & Chile & & Brazil & Argentina & & Chile \\
\hline Constant & 0,125 & & $0,090^{*}$ & $0,052^{*}$ & & 0,222 & $0,034^{*}$ & & $0,242^{*}$ \\
\hline LC & $-0,018^{*}$ & & $-0,038$ * & $-4,04 \mathrm{E}-05$ & & $-0,001$ & $-0,007$ * & & $-2,17 \mathrm{E}-04 * *$ \\
\hline TANG & $-0,015^{\star \star}$ & & 0,015 & $-0,051$ & & $-0,046^{*}$ & $-0,014$ & & $-0,241^{*}$ \\
\hline ROE & $-0,007^{*}$ & & 0,005 & $-0,009$ & & 0,003 & 0,003 & & $-0,066^{* *}$ \\
\hline ROA & $-0,058^{*}$ & & $-0,056 * \star \mid$ & $-0,017$ & & $-0,103^{*}$ & 0,032 & & $-0,086$ \\
\hline CDV & $4,38 \mathrm{E}-04$ & & $-5,83 \mathrm{E}-05$ & $-6,38 \mathrm{E}-07$ & & $-0,001$ & $6,19 \mathrm{E}-04^{*}$ & & $-3,15 \mathrm{E}-06$ \\
\hline CAT & $-0,002$ & & $2,86 \mathrm{E}-04$ & $-4,37 \mathrm{E}-07$ & & $-0,006^{*}$ & $-4,05 \mathrm{E}-05$ & & $-6,88 \mathrm{E}-06$ \\
\hline NPGIR & 0,006 & & $1,47 \mathrm{E}-03$ & $-0,001$ & & 0,001 & $-5,97 \mathrm{E}-05$ & & $-0,005$ \\
\hline ECND & $-8,38 \mathrm{E}-05$ & & $1,43 \mathrm{E}-04$ & $-1,43 \mathrm{E}-04$ & & $-4,58 \mathrm{E}-05$ & $-7,70 \mathrm{E}-05$ & & $-5,95 \mathrm{E}-04$ \\
\hline MTB & $-1,86 \mathrm{E}-07$ & & 0,002 & $-2,11 \mathrm{E}-03$ & & $-3,39 \mathrm{E}-07$ & $-0,005^{\star \star}$ & & $1,33 \mathrm{E}-05$ \\
\hline PLD & $6,51 \mathrm{E}-05$ & & $-0,004$ & $3,13 \mathrm{E}-05^{*}$ & & $-1,47 \mathrm{E}-04$ & $0,006^{*}$ & & $9,72 \mathrm{E}-05^{* *}$ \\
\hline$R^{2}$ & 0,696 & & 0,626 & 0,323 & & 0,774 & 0,774 & & 0,479 \\
\hline$R^{2}$ Tight & 0,656 & & 0,568 & 0,230 & & 0,745 & 0,745 & & 0,407 \\
\hline
\end{tabular}

Source: Prepared by the author (research data).

Ps.: (*) The correlation is significant at the 0.01 level; (**) The correlation is significant at the 0.05 level.

Table 6 shows the determinants that most strongly influence the levels of indebtedness of companies. They are: Current Liquidity (LC), Tangibility (TANG), Return to Shareholders (ROE), Return of Assets (ROA), Sales Growth (CRESCDV), Growth of Assets (CRESCAT), Market-To- Book (MTB) and Business Risk Measured by Volatility of Benefits (PLD). This is close to the results obtained in other research in the area, such as Delcoure (2007), Nakamura et al. (2007), Bastos, Nakamura, and Basso (2009), Bastos and Nakamura (2009), Nunkoo and Boateng (2010), Correa, Basso, and Nakamura (2013) and Póvoa and Nakamura (2015). The analysis of the results is presented in the next section.

The variables of Return to Shareholders (ROE) and Return of Assets (ROA) indicated a negative relationship for the levels of accounting and financial indebtedness. However, only Brazilian companies presented a positive relationship between ROA and short-term indebtedness. These results strongly confirm the $\mathrm{H} 1$ hypothesis, that the relationship between return to shareholders and debt indicators is negative, and 
$\mathrm{H} 2$, that the relationship between return on assets and debt indicators is negative. Similar results are verified in the investigations of Delcoure (2007), Nakamura et al. (2007), Bastos, Nakamura, and Basso (2009), Bastos and Nakamura (2009) and Correa, Basso and Nakamura (2013), in addition to confirming the theory of pecking order.

This negative relationship is due to the fact that internally generated funds from Brazilian, Argentine and Chilean companies do not need to rely so much on external financing, since they use accumulated internal funds from past earnings (Myers, 1984). For Correa, Basso and Nakamura (2013), profitable companies use the resources generated internally to finance the investments of the companies, then third-party resources would be used, through indebtedness, and the last option would be the issuance of new shares.

According to the theory of pecking order, "[...] companies with higher growth rates, which demand more resources than they can generate, would tend to look outside the company for those resources necessary for expansion" (Correa, Basso, \& Nakamura, 2013, p. 110), that is, there should be a positive relationship between growth and debt levels. However, growth opportunities can be seen as intangible assets, thus, "[...] the use of debts would be limited for those companies, which suggests that growing companies should be less indebted" (Correa, Basso, \& Nakamura, 2013, p. 110), that is, there would be a negative relationship, corroborating with the trade-off theory. Thus, hypothesis $\mathrm{H} 3$, that the relationship between asset growth and debt indicators is positive, is confirmed for total and short-term indebtedness for Brazilian companies. For the $\mathrm{H} 4$ hypothesis, that the relationship between sales growth and indebtedness indicators is negative, short-term indebtedness was found in Chilean companies and long-term in Brazilian companies. The findings were also found in the studies of Bastos, Nakamura, and Basso (2009) and Bastos and Nakamura (2009).

The results for the Market-to-Book (MTB) variable, in relation to the levels of indebtedness, were positively significant for Brazilian companies, positively and negatively significant for Argentine companies and not significant for Chilean companies. The negative relationship was also found by the studies of Nakamura et al. (2007) and Nunkoo and Boateng (2010). In addition, the positive and negative relationship was presented by the investigations of Bastos, Nakamura, and Basso (2009) and Bastos and Nakamura (2009). For the pecking order theory, a positive and negative signal is expected for the relationship between MTB and indebtedness (Bastos \& Nakamura, 2009). This ambiguous relationship, according to Bastos, Nakamura, and Basso (2009, p. 69), occurs because companies with higher MTBs "[...] need funds that are often not sufficiently generated by retained benefits or, then, they may have a higher return, depending, therefore, on less debt".

In relation to Tangibility (TANG), there was a negative and significant relationship with the levels of accounting and financial indebtedness for Brazilian and Argentine companies, corroborating the theory of pecking order and rejecting the H5 hypothesis for these two countries. This finding reflects that the managers of Brazilian and Argentine companies, when the composition of tangible assets exerts a strong influence, seek to issue less external debts, as they are less prone to problems of asymmetric information (Myers, 1984).

For Chilean companies, the relationship between Tangibility (TANG) and accounting indebtedness was positive, and for financial indebtedness it was negative, corroborating the theory of trade-off and pecking order, respectively. The findings for the accounting indebtedness allow to accept the H5, of which the relation between tangibility of the assets and the indicators of indebtedness is positive. The studies by Delcoure (2007) and Nunkoo and Boateng (2010) also found a positive relationship. Thus, Chilean companies with high levels of tangibility assume relatively more debts, since tangible assets end up helping companies to incur debts (Titman \& Wessels, 1988), as they are less prone to delinquency (Rajan \& Zingales, 1995).

The Current Liquidity Index (LC) presented a negative relationship for the indebtedness levels of the three countries analyzed, supporting the hypothesis regarding the pecking order theory. Given these results, it can be affirmed that Brazilian, Argentine and Chilean companies that have better liquidity are less prone to the use of external financing. The findings induce the acceptance of the H6 hypothesis, that the relationship between current liquidity and debt indicators is negative. This result goes against the findings of Nakamura et al. (2007), Bastos and Nakamura (2009), Bastos, Nakamura, and Basso (2009) and Póvoa and Nakamura (2015). Thus, managers of companies with greater liquidity prefer to transform company assets into internal financing, as they are less expensive (Myers \& Rajan, 1998), due to the greater financial slack in the 
retention of internally generated funds (Ozkan, 2001).

Finally, some relevant variables lack empirical confirmations, such as the Income Tax Payment Level (NPGIR) and the Fiscal Economy (ECND). These variables, according to trade-off theory, should present significant results, however, for this study, they were unfinished.

\section{Discussion}

The capital structure issue has been thoroughly investigated over more than sixty years, and seems far from exhausted. To define a time base, in the last ten years, research related to the capital structure is broadening the perspectives of new research areas and deepening issues that seemed to be on the edges of exhaustion. Two important works in this regard are: Lemmon, Roberts, and Zender (2008) and Frank and Goyal (2009), which review aspects related to capital structure determinants. It is perceived that, in fact, there is a consensus regarding the determinants of capital structure, together with the question that the two main theories of capital structure (trade-off theory and pecking order theory) are not antagonistic, as the initial works, but complementary, suppose, and this new vision has been defended by various authors in recent years.

This research sought to analyze some determinants of the level of indebtedness of open capital companies in the stock exchanges of Argentina, Brazil and Chile, in the light of the two main theories on the subject. The analyzes were carried out based on data obtained from the financial statements of the open capital companies in the stock exchanges of these countries, in the period from 2007 to 2016. Static and dynamic tests were performed using the panel data model.

In the last 50 years, various works on capital structure have been done around the world, which made this issue become challenging and instigating, once there was not yet a concrete certainty about the explanation of debt indebtedness. Business. This study sought to investigate, then, the determinants of the capital structure of companies belonging to three countries in South America: Argentina, Brazil and Chile. That is, countries that are among the largest economies in the region, despite being emerging countries, guided by an economic ascent from the mid-1990s and with different realities.

Thus, this research analyzed the influence of specific factors of the company that can be decisive in the choice of capital structure, composed of eleven independent variables (Current Liquidity, Tangibility, Return to Investors, Return of assets, Growth of assets sales, Asset Growth, Income Tax payment level, Fiscal Economy, Profitability, Expected Growth by the Market Value Differential and Business Risk Measured by the Volatility of Benefits), explained by the two relevant theoretical trends in terms of volume of theoretical or empirical works: trade-off theory and pecking order.

With respect to the dependent variables (degree of indebtedness), it was objectified in this study to expand the concept of indebtedness based on the choice of five ways of considering the degree of indebtedness, deepening the understanding of the relationship between specific debt factors of the company and the capital structure of the companies. Thus, the dependent variables were chosen: Total indebtedness, Short-term indebtedness, Long-term indebtedness, Short-term burdensome financial indebtedness and Long-term burdensome financial indebtedness. This spectrum of measures takes into account the type and term of indebtedness, allowing a deeper investigation that can reach relevant or innovative conclusions.

The data analyzed reveal that, in the period from 2007 to 2016, among those countries, Brazil is the one with the highest level of total indebtedness, both accounting and financial. For short-term financial indebtedness, Chile has the lowest level, and for the long-term, Argentina predominates. Regarding accounting indebtedness, there is a predominance of long-term debts, with the exception of Argentina, in which the short-term one predominates. Finally, for burdensome financial indebtedness, there is a predominance of expensive long-term debts, except for Argentina, where short-term ones predominate.

It is observed that, with the use of the Panel Data, the determinants that seem to influence the levels of indebtedness of the companies more strongly are: Current Liquidity (LC), Tangibility (TANG), Return to Shareholders (ROE), Return of Assets (ROA), Sales Growth (CRESCDV), Asset Growth (CRESCAT), Market-to-Book (MTB) and Business Risk Measured by Volatility of Benefits (PLD). This conclusion is close to the results obtained by researchers in the area, such as Delcoure (2007), Nakamura et al. (2007), Bastos, Nakamura, and Basso (2009), Bastos and Nakamura (2009), Nunkoo and Boateng (2010), Correa, Basso, and Nakamura (2013) and Póvoa and Nakamura (2015). 
In the present investigation, some relevant independent variables lack empirical confirmations, such as the Income Tax Payment Level (NPGIR) and the Fiscal Economy (ECND). These variables, according to the Trade Off Theory, should present significant results, however, for this study, they were presented inconclusive. It may be that due to the application of these Income Tax Payment Level (NPGIR) and Fiscal Economy (ECND) variables they are applied in developing economies and also that they suffered some decelerations in the period analyzed from 2007 to 2016.

The limitations of this research, as in the others, should be commented to improve further future research, which may deviate from these limitations. First, the limitation was of an econometric order. Panel data can generate several estimation and inference problems, based on cross section data (heterocedasticity) and time series (autocorrelation). Data in static panel were used in this study, which do not allow analyzing the dynamics of debt adjustment over time in view of a supposed metal capital structure.

As for the methods used, dynamic panel data can be used, which may present new evidence, such as the speed of adjustment of the level of accentuation towards an optimal capital structure goal, and if such speed is influenced by macroeconomic and institutional issues . Suggestions for future research, therefore, cover the use of Panel Data to analyze other factors that may influence indebtedness, mainly taxes and dividends, as well as a deeper analysis of factors that may influence the speed of adjustment. towards the target level.

The comparison of results between the various studies that address the capital structure of companies demonstrates the use of a great diversity of proxies, with the intention of measuring certain indicators. Thus, future work could also find out if the proxies used in the main studies really measure what they intend to measure.

Finally, future research could address the influence of the cost of capital in the composition of the debt matrix of the companies listed on the stock exchanges of Argentina, Brazil and Chile.

\section{References}

Abreu, A. F. (2004). Um estudo sobre a estrutura de capital e a política de dividendos considerando a tributação brasileira (Tesis de Maestría). Facultad de Economía, Administración y Contabilidad, Universidad de São Paulo, São $\quad$ Paulo. $\quad$ Retrieved from http://www.teses.usp.br/teses/disponiveis/12/12136/tde-28112005-173537/pt-br.php

Albanez, T. (2009). Impactos da assimetria de informação na estrutura de capital de empresas brasileiras de capital aberto (Tesis de Maestría). Facultad de Economía, Administración y Contabilidad de Ribeirão Preto, Universidad de São Paulo, Ribeirão Preto. Retrieved from http://www.teses.usp.br/teses/disponiveis/96/96133/tde-12052009-155316/pt-br.php

Albuquerque, A. A. (2013). Alavancagem financeira e investimento: um estudo nas empresas brasileiras não financeiras de capital aberto (Tesis de Doctorado). Facultad de Economía, Administración y Contabilidad de Ribeirão Preto, Universidad de São Paulo, Ribeirão Preto. Retrieved from http://www.teses.usp.br/teses/disponiveis/96/96132/tde-28032013-100346/pt-br.php

Allen, N. B., \& Gregory, F. U. (1995) Relationship Lending and Lines of Credit in Small Firm Finance. The Journal of Business, 68(3), 351-381. https://doi.org/10.1086/296668

Altman, E. I. (1984). A further empirical investigation of the bankruptcy cost question. The Journal of Finance, 39(4), 1067-1089. https://doi.org/10.1111/j.1540-6261.1984.tb03893.x

Amaral, P. F. (2011) Decisões de financiamento em empresas brasileiras: uma comparação entre a static tradeoff e a pecking order theory no Brasil (Tesis de Maestría). Facultad de Economía, Administración y Contabilidad de Ribeirão Preto, Universidad de São Paulo, Ribeirão Preto. Retrieved from https://www.teses.usp.br/teses/disponiveis/ 96/96133/tde-26092011-152130/publico/PauloFAmaral.pdf

Anonymous. (1959). The Cost of Capital, Corporate Finance, and the Theory of Investment: Comment. The American Economic Review, 4, 639-55.

Anonymous. (1984). The capital structure puzzle. The Journal of Finance, 39(3), 575-592. https://doi.org/10.2307/2327916

Anonymous. (2007). Avaliação de empresas. São Paulo: Pearson.

Assaf Neto, A. (2010). Finanças corporativas e valor. São Paulo: Atlas.

Balakrishnan, S., \& Fox, I. (1993). Strategic Management Journal, 14(1), 3-16. 
https://doi.org/10.1002/smj.4250140103

Bastos, D. D., \& Nakamura, W. T. (2009). Determinantes da estrutura de capital das companhias abertas no Brasil, México e Chile no período de 2001-2006. Revista Contabilidade \& Finanças, 20(50), 75-94. https://doi.org/10.1590/S1519-70772009000200006

Bastos, D. D., Nakamura, W. T., \& Basso L. F. (2009). Determinantes da estrutura de capital das companhias abertas na América Latina: Um estudo empírico considerando fatores macroeconômicos e institucionais. Revista de Administração Mackenzie, (6), 47-77. https://doi.org/10.1590/S1678-69712009000600005

Bauer, M. W., \& Gaskell, G. (2002). Pesquisa qualitativa com texto, imagem e som: Um manual prático. Petrópolis: Vozes.

Baxter, N. D. (1967). Levarage, risk of ruin and de cost of capital. The Journal of Finance, 22(3), 395-403. https://doi.org/10.1111/j.1540-6261.1967.tb02975.x

Berger, P. G., Ofek, E., \& Yermack, D. L. (1997). Managerial Entrenchment and Capital Structure Decisions. The Journal of Finance, 52(4), 1411-1438. https://doi.org/10.1111/j.1540-6261.1997.tb01115.x

Berlingeri, H. O. (2006). U-shaped cost of equity function? Digging into Modigliani-Miller (1958) mistake. https://doi.org/10.2139/ssrn.934550

Bessler, W., Drobetz, W., \& Kazemieh, R. (2011). Factors affecting capital structure decisions. Capital Structure and Corporate Financing Decisions (pp. 17-40). Hoboken, NJ: John Wiley. https://doi.org/10.1002/9781118266250.ch2

Bhattacharya, S. (1988). Corporate finance and the legacy of Miller and Modigliani. The Journal of Economic Perspectives, 2(4), 135-147. https://doi.org/10.1257/jep.2.4.135

Booth, L., Aivazian, V., Demirguc-Kunt, A., \& Maksimovic, V. (2001). Capital structures in developing countries. The Journal of Finance, 56(1), 87-130. https://doi.org/10.1111/0022-1082.00320

Bowman, E. H. (1980). A risk/return paradox for strategic management. Sloan Management Review, 21, 17-31.

Bradley, M., Jarrell, G. A., \& Kim, E. H. (1984). On the Existence of an Optimal Capital Structure: Theory and Evidence. Journal of Finance, 39(3), 857-78. https://doi.org/10.1111/j.1540-6261.1984.tb03680.x

Brealey, R. A., Myers, S. C., \& Allen, F. (2010). Principles of corporate finance. New York: McGraw-Hill Irwin. Retrieved

from http://www.competitiontribunal.gov.au/_data/assets/pdf_file/0004/28246/END.042.001.0013.pdf

Brealey, R. A., Myers, S. C., \& Marcus, A. J. (2002). Fundamentos da administração financeira. Rio de Janeiro: McGraw-Hill.

Brennan, M. J., \& Schwartz, E. S. (1985). Evaluating Natural Resource Investments. Journal of Business, 58, 135-157. https://doi.org/10.1086/296288

Brennan, M., \& Kraus, A. (1987). Efficient Financing under Asymmetric Information. Journal of Finance, 42(5), 1225-43. https://doi.org/10.1111/j.1540-6261.1987.tb04363.x

Brito, G., Corrar, J., \& Bastitella, F. (2007). Fatores determinantes da estrutura de capital das maiores empresas que atuam no Brasil. Revista Contabilidade \& Finanças - USP, (43), 9-19. https://doi.org/10.1590/S1519-70772007000100002

Brito, R. D., \& Silva, J. C. G. (2005). Testando as previsões de trade-off e pecking order sobre dividendos e $\begin{array}{llllll}\text { dívida para o } & \text { Brasil. Estudos Econômicos } & \text { (IPE/USP), } & 35(1), & \text { 37-79. }\end{array}$ https://doi.org/10.1590/S0101-41612005000100002

Brooks, C. (2008). Introductory econometrics for finance. Cambridge: Cambridge University Press. https://doi.org/10.1017/CBO9780511841644

Caglayan, E., \& Sak, N. (2010). The determiants of capitl structure: Evidence from the Turkish Banks. Journal of Money, Investiment and Banking, (15), 57-65.

Cameron, A. C., \& Trivedi, P. K. (2005). Microeconometrics: methods and applications. Cambridge: Cambridge University Press. https://doi.org/10.1017/CBO9780511811241

Camilo, S. P., Xavier, W. G., De Mello, R. B., \& Marcon, R. (2010). A estrutura de capital como recurso e o efeito no desempenho das firmas. Revista Ibero-Americana de Estratégia, 9(1), 102-126. https://doi.org/10.5585/riae.v9i1.1661 
Campos, A., Nakamura, W. T. (2013). Folga Financeira Avaliada como Endividamento Relativo e Estrutura de Capital. Revista de Finanças Aplicadas, 1(1), 1-19. Retrieved from http://www.financasaplicadas.net/index.php/financasaplicadas/article/view/87/pdf

Choi, D. Y., Saito, R., \& Silva, V. A. B. (2015). Estrutura de capital e remuneração dos funcionários: Evidência empírica no Brasil. Revista de Administração Contemporânea, 19(2), 249-269. https://doi.org/10.1590/1982-7849rac20151600

Constantinides, G. M., \& Grundy, B. D. (1989). Optimal Investment with Stock Repurchase and Financing as Signals. The Review of Financial Studies, 2, 445-465. https://doi.org/10.1093/rfs/2.4.445

Cooper, D. R., \& Schindler, P. S. (2003). Métodos de pesquisa em administração. Porto Alegre: Bookman.

Copeland, T., Weston, J., \& Shastri, K. (2005). Financial Theory and corporate policy. USA: Pearson.

Corrar, L. J., Paulo, E., \& Dias Filho, J. M. (2007). Análise Multivariada: Para cursos de administração, ciências contábeis e economia. São Paulo: Atlas/FIPECAFI.

Correa, C. A. (2006). A Estrutura de capital das maiores empresas brasileiras: análise empírica usando Painel Data (Tesis de Maestría). Universidad Presbiteriana Mackenzie, São Paulo. Retrieved from http://tede.mackenzie.br/jspui/handle/tede/517

Correa, C. A., Basso, L. F. C., \& Nakamura, W. T. (2007). What determines the capital structure of the largest Brazilian firms? An empirical analisys using panel data. https://doi.org/10.2139/ssrn.989047

Correa, C. A., Basso, L. F. C., \& Nakamura, W. T. (2013). A estrutura de capital das maiores empresas brasileiras: Análise empírica das teorias de Pecking Order e trade-off, usando panel data. RAM, Rev. Adm. Mackenzie, 14(4), 106-133. https://doi.org/10.1590/S1678-69712013000400005

Daher, C. E. (2004). Testes empíricos de teorías alternativas sobre a determinação da estrutura de capital das empresas brasileiras (Tesis de Maestría). Brasília: UnB, UFPB, UFPE, UFRN.

Damodaran, A. (2001). Corporate finance: Theory and practice. USA: Wiley.

Deangelo, H., \& Masulis, R. (1980). Optimal Capital Structure Under Corponte Taxation. Journal of Financial Economics, 8, 5-29. https://doi.org/10.1016/0304-405X(80)90019-7

Deesomsak, R., Paudyal, K., \& Pescetto, G. (2004). The determinants of capital structure: Evidence from the Asia Pacific region. Journal of Multinational Financial Management, 14, 387-405. https://doi.org/10.1016/j.mulfin.2004.03.001

Delcoure, N. (2007). The determinants of capital structure in transitional economies. International Review of Economics \& Finance, 16(3), 400-415. https://doi.org/10.1016/j.iref.2005.03.005

Demirgüç-Kunt, A., \& Maksimovic, V. (1996). Stock market development and financing choices of firms. World Bank Economic Review, 10, 341-369. https://doi.org/10.1093/wber/10.2.341

Demirgüç-Kunt, A., Peria, M. S. M., \& Tressel, T. (2020). The global financial crisis and the capital structure of firms: Was the impact more severe among SMEs and non-listed firms? Journal of Corporate Finance, 60, Febr. https://doi.org/10.1016/j.jcorpfin.2019.101514

Donaldson, G. (1961). Corporate debt capacity: A study of corporate debt policy and the determination of corporate debt capactiy. Boston: Division of Research, Harvard School of Business Administration.

Donato, L. G. (2011). Liquidez e estrutura de capital das empresas brasileiras de capital aberto (Teses de Maestría). Escuela de Ingeniería de São Carlos, Universidad de São Paulo, São Carlos. Retrieved from http://www.teses.usp.br/teses/disponiveis/18/18157/tde-10112011-155426/pt-br.php

Dumrauf, G. L. (2001). La estructura de capital óptima de la firma, implicancias para las decisiones de inversión y financiamiento (Tesis de Doctorado). Buenos Aires: Facultad de Ciencias Económicas. Retrieved from http://bibliotecadigital.econ.uba.ar/download/tesis/1501-1160_LopezDurmraufG.pdf

Durand, D. (1952). Cost of debt and equity funds for business: trends and problems in measurement. In Proceeding of the Conference on Research in Business Finance (1952, pp. 215-262). New York, National Bureau of Economic Research.

Fama, E., \& French, K. (2002). Testing Trade-Off and Pecking Order Predictions about Dividends and Debt. The Review of Financial Studies, 15(1), 1-33. https://doi.org/10.1093/rfs/15.1.1

Fama, E., \& French, K. (2005). Financing decisions: Who issues stock? Journal of Financial Economics, 76, 
549-582. https://doi.org/10.1016/j.jfineco.2004.10.003

Famá, R., Barros, L. A. B. C., \& Silveira, A. M. (2001). A estrutura de capital é relevante? Novas evidências a partir de dados norteamericanos e latino-americanos. Caderno de Pesquisa em Administração, 8(2), 71-84.

Favato, V., \& Rogers, P. (2008). Estrutura de capital na América Latina e nos Estados Unidos: Uma análise de seus determinantes e efeito dos sistemas de financiamento. Gestão \& Regionalidade, 24(71), 31-43. Retrieved from http://seer.uscs.edu.br/index.php/revista_gestao/article/download/90/52

Fávero, L. P., Belfiore, P., Silva, F. L., \& Chan, B. L. (2009). Análise de dados: Modelagem multivariada para tomada de decisões. Rio de Janeiro: Elsevier.

Fernandez, P. (1999). Equivalence the different discounted cash flow valuation methods. Different alternatives for determining the discounted value of shields and their implications for the valuation. Barcelona: IESE. https://doi.org/10.2139/ssrn.182308

Ferreira, R. M., Bertucci, L. A., \& Filho, A. D. P. (2010). Relação entre estrutura de capitais e estrutura de ativos nos setores brasileiros de energia elétrica e Telecomunicações. Revista Brasileira De Gestão De Negócios, 12(34), 7-24. Retrieved from https://search.proquest.com/docview/1021187489?accountid=26670

Ferri, M. G., \& Jones, W. H. (1979). Determinants of financial structure: A nem methodological approach. Journal of Finance, 34, 631-644. https://doi.org/10.1111/j.1540-6261.1979.tb02130.x

Frank, M. Z., \& Goyal, V. K. (2003). Testing the pecking order theory of capital structure. Journal of Financial Economics, 67(2), 217-248. https://doi.org/10.1016/S0304-405X(02)00252-0

Frank, M. Z., \& Goyal, V. K. (2008). Trade-off and pecking order theories of debt. In B. E. Eckbo (Ed.), Handbook of Corporate Finance: Empirical Corporate Finance (Vol. 2, pp. 135-202).

Frank, M. Z., \& Goyal, V. K. (2009). Capital structure decisions: Which factors are reliably important? Financial Management, 38(1), 1-37. https://doi.org/10.1111/j.1755-053X.2009.01026.x

Gaud, P., Jani, E., Hoesli, M., \& Bender, A. (2005). The Capital Structure of Swiss Companies: An Empirical Analysis Using Dynamic Panel Data. European Financial Management, 11(1), 51-59. https://doi.org/10.1111/j.1354-7798.2005.00275.x

Gomes, G. L., \& Leal, R. P. C. (2001). Determinantes da Estrutura de Capitais das Empresas Brasileiras com Ações Negociadas em Bolsas de Valores. In R. P. C. Leal et al. (Eds.), Finanças Corporativas. São Paulo: Atlas.

Graham, J. K. (1996). Debt and the marginal tax rate. Journal of Financial Economics, 41-73. https://doi.org/10.1016/0304-405X(95)00857-B

Gujarati, D. N., \& Porter, D. C. (2011). Econometria básica. Porto Alegre: AMGH.

Gungoraydinoglu, A., \& Oztekin, O. (2011). Firm - and country level determinants of corporate leverage: Some new international evidence. Journal of Coporate Finance, 17, 1457-1474. https://doi.org/10.1016/j.jcorpfin.2011.08.004

Hair, J. F., Anderson, R. E., Tatham, R. L., \& Black, W. C. (2005). Análise multivariada de dados. Porto Alegre: Bookman.

Harris, M., \& Raviv, A. (1991). The theory of optimal capital structure. Journal of Finance, 48, 297-356. https://doi.org/10.1111/j.1540-6261.1991.tb03753.x

Hegenberg, L. (1976). Etapas da investigação científica. São Paulo: EPU-EDUSP.

Heinkel, R., Zechner, J. (1990). The Role of Debt and Perferred Stock as a Solution to Adverse Investment Incentives. Journal of Financial and Quantitative Analysis, 25(1), 1-24. https://doi.org/10.2307/2330885

Hovakimian, A., \& Li, G. (2011). In search of conclusive evidence: How to test for adjustment to target capital structure. Journal of Corporate Finance, 17, 33-44. https://doi.org/10.1016/j.jcorpfin.2010.07.004

Hovakimian, A., Opler, T., \& Titman, S. (2001). The debt equity choice. Journal of Financial and Quantitative Analysis, 36(1), 1.

Hsiao, C. (2005). Why Panel Data? IEPR Working Papers 05.33, Institute of Economic Policy Research (IEPR). Retrieved from https://papers.ssrn.com/sol3/papers.cfm?abstract_id=820204

Iara, R. N. (2013). Análise da estrutura de capital em empresas brasileiras com diferentes níveis de endividamento: Um estudo comparativo entre as teorias pecking order e trade off (Tesis de Maestría). 
Facultad de Economía, Administración y Contabilidad de Ribeirão Preto, Universidad de São Paulo, Ribeirão Preto. Retrieved from http://www.teses.usp.br/teses/disponiveis/96/96133/tde-23012014-105642/publico/ReniellyNIara_Original. pdf

Jensen, M. C., \& Meckling, W. H. (1976). Theory of the firm: Managerial behavior, agency costs and ownership structure. Journal of Financial Economics, 3, 305-360. https://doi.org/10.1016/0304-405X(76)90026-X

Johnson, R. A., \& Wichern, D. W. (1998). Applied multivariate statistical analysis. New Jersey: Prentice Hall. https://doi.org/10.2307/2533879

Jong, A., Kabir, R., \& Nguyen, T. T. (2008). Capital structure around the word: The roles of firm and country specific determinants. Journal of Banking \& Finance, 32, 1954-1969. https://doi.org/10.1016/j.jbankfin.2007.12.034

Jucá, M. N. (2011). Determinantes da estrutura de capital de bancos brasileiros e norte-americanos (Tesis de Doctorado). Facultad de Economía, Administración y Contabilidad, Universidad de São Paulo, São Paulo. Retrieved from http://www.teses.usp.br/teses/disponiveis/12/12139/tde-27012012-192849/pt-br.php.

Kahle, K., \& Shastri, K. (2005). Firm Performance, Capital Structure, and the Tax Benefits of Employee Stock Options. Journal of Financial and Quantitative Analysis, 40(1), 135-160. https://doi.org/10.1017/S0022109000001770

Kayo, E. K., \& Famá, R. (1997). Teoria de agencia e crescimento: Evidencias empíricas dos efeitos positivos e negativos do endividamento. Caderno de Pesquisa em Administração, 2(5), 1-8.

Kayo, E. K., \& Kimura, H. (2011). Hierarchical determinants of capital structure. Journal of Banking \& Finance, 35, 358-371. https://doi.org/10.1016/j.jbankfin.2010.08.015

Kochhar, R. (1997). Strategic assets, capital structure, and firm performance. Journal of Financial and Strategic $\begin{array}{lll}\text { Decisions. } & 10(3) . & \text { Retrieved } \\ \text { http://www.financialdecisionsonline.org/archive/pdffiles/v10n3/kochhar.pdf }\end{array}$

Krasker, W. S. (1986). Stock Price Movements in Response to Stock Issues under Asymmetric Information. Journal of Finance, 41(1), 93-105. https://doi.org/10.1111/j.1540-6261.1986.tb04493.x

Lemmon, M. L., Roberts, M. R., \& Zender, J. F. (2008). Back to the Beginning: Persistence and the Cross-Section of Corporate Capital Structure. The Journal of Finance, 63(4), 1575-1608. https://doi.org/10.1111/j.1540-6261.2008.01369.x

López-Morales, J. S., \& Vargas-Henández, J. G. (2014). Effect of the type of ownership in the financial performance: The case of firms in latin america. International Business Research, 7(10), 125-132. https://doi.org/10.5539/ibr.v7n10p125

Lucey, B. M., \& Zhang, Q. (2011). Financial integration and emerging markets capital structure. Journal of Banking \& Finance, 35, 1228-1238. https://doi.org/10.1016/j.jbankfin.2010.10.017

Lumby, S. (1991). Investment Appraisal and Financing Decisions (3rd ed.). Van Nostrand Reinhold (UK).

Mamede, S. de P. N., Jardim, J. R. de P. S., Nakamura, W. T., Jones, G. D. C., Nakamura, E. A. M. V. (2019). Does the capital concentration level influence the Brazilian companies capital structure? Revista de Administração da Universidade Federal de Santa Maria, 12(4), 785-802. https://doi.org/10.5902/1983465923841

Marcon, R., Grzebieluckas, C., Mello, R. B., \& Muller, R. A. (2007). O comportamento da estrutura de capital e a performance de firmas brasileiras, argentinas e chilenas. Revista de Gestão USP, 14(2), 33-48. Retrieved from https://www.revistas.usp.br/rege/article/view/36596

Marconi, M. A., \& Lakatos, E. M. (2011). Metodologia científica. São Paulo: Atlas.

Marques, J. H. F. (2000). Perspectivas internacionales en la historia de la psicología en Portugal. Revista de Psicologia Geral y Aplicada, 53, 599-606.

Medeiros, O. R., \& Daher, C. E. (2008). Testando teorias alternativas sobre a estrutura de capital nas empresas $\begin{array}{lllll}\text { brasileiras. Revista de Administração } & \text { Contemporânea, } & \text { 12(1), }\end{array}$ https://doi.org/10.1590/S1415-65552008000100009

Mehran, H. (1992). Executive incentive plans, corporate control and capital structure. The Journal of Financial and Quantitative Analysis, 27(4), 539-560. https://doi.org/10.2307/2331139 
Mendonça, F. F. P., Martins, H. C., \& Terra, P. R. S. (2019). Estrutura de Capital e Mecanismos de Governança Externos à Firma: Uma Análise Multipaís. Revista de Administração Contemporânea, 23(6), 765-785. https://doi.org/10.1590/1982-7849rac2019190109

Modigliani, F., \& Miller, M. (1958). The cost of capital, corportation finance and the theory of investment. The American Economic Review, 433-443. https://doi.org/10.1086/294442

Modigliani, F., \& Miller, M. (1961). Dividend politicy, growth and the valuation of shares. Journal of Business, 411-433.

Modigliani, F., \& Miller, M. (1963). Corporate Income Taxes and the Cost of Capital: A Correction. The American Economic Review, 53(3), 433-443. Retrieved from https://www2.bc.edu/thomas-chemmanur/phdfincorp/MF891\%20papers/MM1963.pdf.

Muritiba, S. N. (2005). Participação dos conselhos de administração na estratégia empresarial no âmbito da governança corporativa (Tesis de Maestría). Facultad de Economía, Administración y Contabilidad, Universidad de São Paulo, São Paulo.

Myers, S. C. (2001). Capital structure. The Journal of Economic Perspectives, 15(2), 81-102. https://doi.org/10.1257/jep.15.2.81

Myers, S. C., \& Majluf, N. (1984). Corporate Financing and Investment Decisions When Firms Have Information that Investors Do Not Have. Journal of Financial Economics, 13(2), 187-221. https://doi.org/10.1016/0304-405X(84)90023-0

Myers, S. C., \& Rajan, R. G. (1998). The Paradox of Liquidity. The Quarterly Journal of Economics, 113(3), 733-771. https://doi.org/10.1162/003355398555739

Nakamura, W. T., Martin, D. M. L., \& Kayo, E. K. (2004). Proposta para a determinação da estrutura de capital ótima, na prática. Revista de Administração UNISAL, Americana, l(1).

Nakamura, W. T., Martin, D. M. L., \& Kimura, H. (2004). Novas evidências sobre estrutura de capital no Brasil. In P. P. Cladea (Ed.), Anais. Puerto Plata: Pontificia Universidad Católica Madre y Maestra.

Nakamura, W. T., Martin, D. M. L., Forte, D., Filho, A. F. C., Costa, A. C. F., \& Amaral, A. C. (2007). Determinantes de estrutura de capital no mercado brasileiro: Análise de regressão com painel de dados no período 1999-2003. Revista Contabilidade \& Finanças, 18(44), 72-85. https://doi.org/10.1590/S1519-70772007000200007

Narayanan, M. P. (1988). Debt versus equity under asymmetric information. Journal of Financial and Quantitative Analysis, 23, 39-51. https://doi.org/10.2307/2331023

Noe, T. H. (1988). Capital Structure and Signaling Game Equilibria. The Review of Financial Studies, 1(4), 331-355. https://doi.org/10.1093/rfs/1.4.331

Nunkoo, P. K., \& Boateng, A. (2010). The empirical determinants of target capital structure and adjustment to long-run target: Evidence from Canadian firms. Applied Economics Letters, 17(10), 983-990. https://doi.org/10.1080/17446540802599671

Oliva, E. C., \& Albuquerque, L. G. (2006). Filosofia e modelo dos programas de remuneração das empresas que aderiram aos níveis diferenciados de governança corporativa da bovespa. Revista de Gestão, 13(2), 79-96. Retrieved from http://www.revistas.usp.br/rege/article/download/36560/39281/

Ozkan, A. (2001). Determinants of Capital Structure and Adjustment to Long Run Target: Evidence From UK Company Panel Data. Journal of Business Finance \& Accounting, 28, 175-198. https://doi.org/10.1111/1468-5957.00370

Patterson, H. D., \& Thompson, R. (1971). Recovery of inter-block information when block sizes are unequal. Biometrika, 58, 545-54. https://doi.org/10.1093/biomet/58.3.545

Perobelli, F. F. C., \& Famá, R. (2003). Fatores determinantes da estrutura de capital para empresas latino-americanas. Revista De Administração Contemporânea, 7(1), 9-35, 226-230. https://doi.org/10.1590/S1415-65552003000100002

Popper, K. R. (1975). Conhecimento objetivo. São Paulo: Edusp.

Póvoa, A. C. S., \& Nakamura, W. T. (2015). Relevância da estrutura de dívida para os determinantes da estrutura de capital: um estudo com dados em painel. Revista Contemporânea de Contabilidade, 12(25), 3-25. https://doi.org/10.5007/2175-8069.2015v12n25p03 
Prates, C. P. T., \& Leal, R. P. C. (2005). Algumas considerações sobre os determinantes da estrutura de capital nas empresas brasileiras. Revista do BNDES, 12(2/3), 201-218.

Raifur, L., \& Sousa, A. F. (2011). A alavancagem financeira e os efeitos no beta: Um estudo das empresas do setor de metalurgia e siderurgia na Bovespa. Revista Contabilidade e Controladoria, 3, 6-26.

Rajan, R., \& Zingales, L. (1995). What do we know about capital structure? Some evidence from international data. Journal of Finance, (50), 1421-1460. https://doi.org/10.1111/j.1540-6261.1995.tb05184.x

Ramos Júnior, F. P., Santos, I., Gaio, L. E., Stefanelli, N. O., \& Passos, I. C. (2019). Capital structure of Brazilian public companies: Normality, global fnancial crisis and economic recession. Contaduría y Administración, 64(1), 1-15. https://doi.org/10.22201/fca.24488410e.2018.1152

Remmers, L., Stonehill, A., Wright, R, Beekhuisen, T. (1974) Industry and size as debt ratio determinants in manufacturing internationally. Financial Management, 24-32. https://doi.org/10.2307/3665286

Ross, S. A. (1977). The determination of financial structure: The incentive signalling approach. Bell Journal of Economics, (8), 23-40. https://doi.org/10.2307/3003485

Ross, S. A., Westerfield, R. W., \& Jaffe, J. F. (1995). Administração Financeira. São Paulo: Atlas.

Ross, S. A., Westerfield, R. W., \& Jordan, B. D. (2008). Administração financeira. São Paulo: MCGraw- Hill.

Rossoni, L., \& Machado-da-Silva, C. L. (2010). Institucionalismo organizacional e práticas de governança $\begin{array}{llll}\text { corporativa. Revista de Administração } & \text { Contemporânea, } & \text { 14(spe), } & \text { 173-198. }\end{array}$ https://doi.org/10.1590/S1415-65552010000600008

Sandberg, C. M., Lewellen, W. G., \& Stakey, K. L. (1987). Financial strategy: planning and managing the corporate leverage position. Strategic Management Journal, 8. https://doi.org/10.1002/smj.4250080103

Santos, C. M. (2006). Levantamento dos fatores determinantes da estrutura de capital das empresas brasileiras (Tesis de Maestría). Facultad de Economía, Administración y Contabilidad de Ribeirão Preto, Universidad de São Paulo, Ribeirão Preto. Retrieved from http://www.teses.usp.br/teses/disponiveis/96/96132/tde-24012007-112641/pt-br.php.

Schmitt, F. O. V. (2004). Os determinantes da estrutura de capital das empresas brasileiras (Tesis de Doctorado). Facultad de Economía, Administración y Contabilidad, Universidad de São Paulo, São Paulo.

Scott, D. F., Jr., \& John, D. M. (1975). Industry influence on financial structure. Financial Management, 4, 67-73. https://doi.org/10.2307/3665473

Shyam-Sunder, L, \& Myers, S. C. (1999). Testing static tradeoff against pecking order models of capital structure. Journal of Financial Economics, 51(2), 219-244. Retrieved from https://pdfs.semanticscholar.org/8ecf/61595b42ad97df818edecd79e1b1719e02a5.pdf.

Silva, S. B. (2018). Estrutura de capital e diversificação de negócios de empresas brasileiras (Tesis de Doctorado). Universidad Presbiteriana Mackenzie, São Paulo. Retrieved from http://tede.mackenzie.br/jspui/bitstream/tede/3678/5/SANDRO\%20BRAZ\%20SILVA.pdf.

Silveira, A. D. M., Perobelli, F. F. C., \& Barros, L. A. B. C. (2008). Governança Corporativa e os determinantes da estrutura de capital: evidências empíricas no Brasil. Revista de Administração Contemporânea, 12(3), 763-788. https://doi.org/10.1590/S1415-65552008000300008

Smith, C., \& Warner, C. (1979). On financial contracting: an analysis of bond convenants. Journal of Financial Economics, (7), 117-161. https://doi.org/10.1016/0304-405X(79)90011-4

Stanley, P., \& Gale, C. (2012). The miller-modigliani 1961 ponzi scheme, alias "dividend irrelevance". International Journal of Law and Management, 54(3), 234-241. https://doi.org/10.1108/17542431211228638

Stonehill, A., Beekhuisen, T., Wright, R., \& Remmers, L. (1975)。 Financial goals and debt ratio determinants: A survey of practice in five countries. Financial Management, 27-33. https://doi.org/10.2307/3665187

Tapia, G., \& Albornoz, C. (2017). Tratado de finanzas, negocios, empresas y organizaciones. Buenos Aires: Thomson Reuters.

Theóphilo, C. R., \& Martins, G. A. (2009). Metodologia da investigação científica para ciências sociais aplicadas. São Paulo: Atlas.

Thies, C. F., \& Klock, M. S. (1992). Determinants of Capital Structure. Review of Financial Economics. 
https://doi.org/10.1002/j.1873-5924.1992.tb00548.x

Titman, S., \& Wessels, R. (1988). The determinants of capital structure choice. Journal of Finance, 43(1), 1-19. https://doi.org/10.1111/j.1540-6261.1988.tb02585.x

Toy, N., Stonehill, A., Remmers, L., \& Wright, R. (1974) A comparative international study of growth, profitability and risk as determinants of corporate debt ratios in the manufacturing sector. Journal of Finance and Quantitative Analysis, 875-886. https://doi.org/10.2307/2329684

Vélez-Pareja, I. (2010). Risky tax shields and risky debt: An exploratory study. Cuadernos de Administración, 23(41), 185-211. Retrieved from http://www.scielo.org.co/scielo.php?script=sci_arttext\&pid=S0120-35922010000200010\&lng=en\&tlng=en

Warner, J. B. (1977). Bankruptcy costs: Some evidence. The Journal of Finance, 32(2), 337-347. https://doi.org/10.2307/2326766

Weston, J. F., \& Brigham, E. (1981). Managerial finance. Hinsdale: Dryden Press.

Wooldridge, J. M. (2006). Introductory Econometrics: A Modern Approach. South-Western: Thomson.

Wooldridge, J. M. (2009). Introductory Econometrics: A modern Approach. Cengage Learning.

Wooldridge, J. M. (2010). Econometric analysis of cross section and panel data. London: MIT Press.

Zavala, M. R. V., \& Salgado, R. J. S. (2019). Empirical evidence on the relationship of capital structure and market value among Mexican publicly listed companies Evidencia empírica sobre la relación de estructura de capital y valor entre empresas mexicanas listadas en bolsa. Contaduría y Administración, 64(1), 1-29. https://doi.org/10.22201/fca.24488410e.2018.1377

\section{Copyrights}

Copyright for this article is retained by the author(s), with first publication rights granted to the journal.

This is an open-access article distributed under the terms and conditions of the Creative Commons Attribution license (http://creativecommons.org/licenses/by/4.0/). 